\title{
Association of chagasic megacolon and cancer of the colon: case report and review of the literature
}

\author{
Associação de megacólon chagásico e câncer de cólon: \\ relato de caso e revisão da literatura \\ Sheila Jorge Adad', Renata Margarida Etchebehere², José Ribamar de Araújo², \\ Andrea Berdu Madureira ${ }^{3}$, Vanessa Guimarães Freitas Lima ${ }^{3}$, \\ Alex Augusto da Silva ${ }^{3}$ and Eduardo Crema ${ }^{3}$
}

\begin{abstract}
There are few descriptions of association between chagasic megacolon and colon cancer. We report a case of obstructive abdomen caused by adenocarcinoma of the left colon in chagasic megacolon. A review of the literature revealed 8 cases of this association and, analyzing together the series of findings of cancer in chagasic organomegalies, we found a frequency of $4.8 \%$ in megaesophagus and $0.1 \%$ in megacolon.

Key-words: Chagas' disease. Chagasic megacolon. Colorectal cancer. Cancer in organomegalies.
\end{abstract}

Resumo Há poucas descrições de associação entre megacólon chagásico e câncer de cólon. Relatamos caso de abdômen obstrutivo por adenocarcinoma do cólon esquerdo, em megacólon chagásico. A revisão da literatura indica 8 casos desta associação e, analisando-se em conjunto as séries de levantamentos de câncer em megas chagásicos, encontra-se freqüência de 4,8\% em megaesôfago e 0,1\% em megacólon.

Palavras-chaves: Doença de Chagas. Megacólon chagásico. Câncer colo-retal. Câncer em visceromegalias.

The association between the digestive form of Chagas' disease and malignant neoplasias has been described by diverse authors, specially with esophagopathy, varying from 3.4 to $9.2 \% 4614181920252930$. Only in the study by Rezende et $\mathrm{al}^{28}$, cancer of the esophagus and megaesophagus association was lower than those reported; this may be due to the inclusion of early cases of megaesophagus. Simple infection with $T$. cruzi does not justify such an association, as there is no increase in frequency of cancer of the esophagus in chagasic patients without mega-organs ${ }^{29}$. On the other hand, the presence of the mega-organ appears to be a determinant, given that neoplasias are also seen to appear in individuals with idiopathic achalasia ${ }^{12} 1831$. This could be explained especially by the dilatation of the organ and the consequent alimentary stasis, setting off esophagitis and/or prolonged contact between the alimentary carcinogenic agents and the mucosa ${ }^{17}$. Gastroesophageal reflux, which also induces chronic irritation of the mucosa, is uncommon in non- treated megaesophagus ${ }^{28}$. Nevertheless, there does not appear to be greater incidence of colorectal cancer in megacolon, despite the existence of dilatation and fecal stasis. This observation is reinforced by some studies ${ }^{182030}$, including work done in our region ${ }^{20}$. In this latter study, from 4,690 necropsies performed, $13(0.4 \%)$ cases of colorectal cancer were diagnosed among the 2,984 nonchagasic cases, and $6(0.4 \%)$ cases of this neoplasia among the 1,508 chagasic cases without megacolon. Among the 198 necropsies performed on chagasic patients with megacolon, there was only $1(0.5 \%)$ case of colorectal cancer, localized in the rectum. A review of the literature showed only 8 references to an association between colorectal cancer and chagasic megacolon, of which only three cases were described with clinical and/or anatomicopathological details ${ }^{2125}$.

In this report, we present a case of chronic obstructive abdomen caused by neoplasia of the left colon in a chagasic megacolon sufferer.

\footnotetext{
1. Disciplina de Patologia Especial; 2. Curso de Pós-graduação em Patologia; 3 . Disciplina de Cirurgia do Aparelho Digestivo da Faculdade de Medicina do Triângulo Mineiro, Uberaba, MG, Brazil.

Financial support: Conselho Nacional de Desenvolvimento Científico e Tecnológico (CNPq), Fundação de Amparo à Pesquisa de Minas Gerais (FAPEMIG ), Fundação de Ensino e Pesquisa de Uberaba (FUNEPU)

Address to: Dra Sheila Jorge Adad. Disc. de Patologia Especia/HE/FMTM. R. Getúlio Guaritá 130, Abadia, 38025-440 Uberaba-MG, Brasil.

Tel: 5534 3318-5152; Fax: 5534 3312-6640

e-mail: pe fmtm@mednet.com.br

Recebido para publicação em 24/05/2001.
} 


\section{CASE REPORT}

A 60-year-old white male, native and resident in Uberaba, Minas Gerais, Brazil. The patient was admitted to emergency room with abdominal cramps, abdominal distension and stoppage of bowel movements four days before. He denied having fever or vomiting. He reported having had a similar condition one month before, and chronic constipation. He denied having a tobacco or alcohol addiction. There was no familial history of colon cancer.

On physical examination, the patient showed good conditions with minimal signs of dehydration. The abdomen was distended, with raised levels and timbre of water-air noises, and diffuse tympanites. Superficial and deep abdominal palpation was without pain or resistance. Rectal inspection was normal. A simple radiological examination showed generalized distension of the colon and liquid level. Rectosigmoidoscopy, to a depth of $25 \mathrm{~cm}$, did not show evidence of fecaloma or volvulus. A barium enema demonstrated dilatation of the colon and rectum, with an irregular area of narrowing in the sigmoid suggestive of neoplasia causing stenosis (Figure 1). Serology for Chagas' disease was positive using three different techniques (complement fixation, immunofluorescence and hemagglutination).

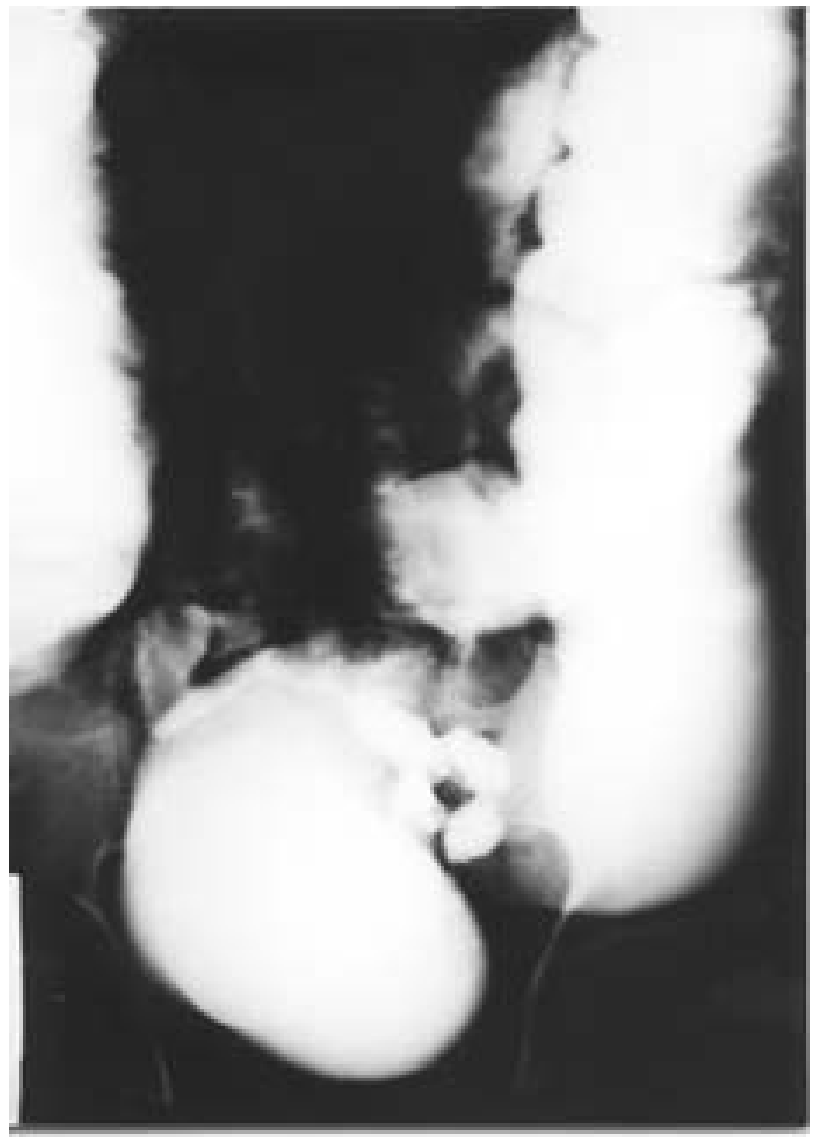

Figure 1 - Barium enema demonstrating dilatation of the colon and rectum, with an irregular area of narrowing in the sigmoid, suggestive of neoplasia.
Exploratory laparotomy was performed, during which an annular lesion was detected in the sigmoid, with great distension of the loops of both small and large intestine. Hartman's procedure was chosen for the treatment, with oncological rectosigmoidectomy, closure of the rectal stump at the level of the middle rectum, and exteriorization of the descending colon in the left iliac fossa, with construction of a left terminal colostomy with early maturation.

Anatomicopathological examination of the resected large intestine segment, which measured $33 \mathrm{~cm}$, showed annular tissue neoformation causing stenosis, measuring $4 \times 3.5 \mathrm{~cm}$, which was ulcerated and infiltrating all the layers (Figure 2). The proximal segment was presented dilated with a perimeter of $14 \mathrm{~cm}$, hypertrophied wall with a total thickness of $0.8 \mathrm{~cm}$ of which $0.6 \mathrm{~cm}$ corresponded to the muscle tunica, and the taenia were shown to be spread out. The segment distal to the neoplasia had a perimeter of $6 \mathrm{~cm}$, a wall with a thickness of $0.4 \mathrm{~cm}$ with discrete thickening of the muscle tunica $(0.3 \mathrm{~cm})$, and multiple pseudo-diverticula were also noted. There was also a polyp of $1 \times 0.7 \mathrm{~cm}$ close to the distal margin and an ulcer of $0.6 \times 0.5 \mathrm{~cm}$ at the proximal margin. Microscopically, the neoplasia corresponded to a moderately differentiated adenocarcinoma, invading the pericolic fat, with metastases in two of 16 mesocolon lymph nodes. The single polyp described was of hyperplastic type, and the ulcer had an appearance compatible with an ischemic lesion. Distant from the tumor, there was

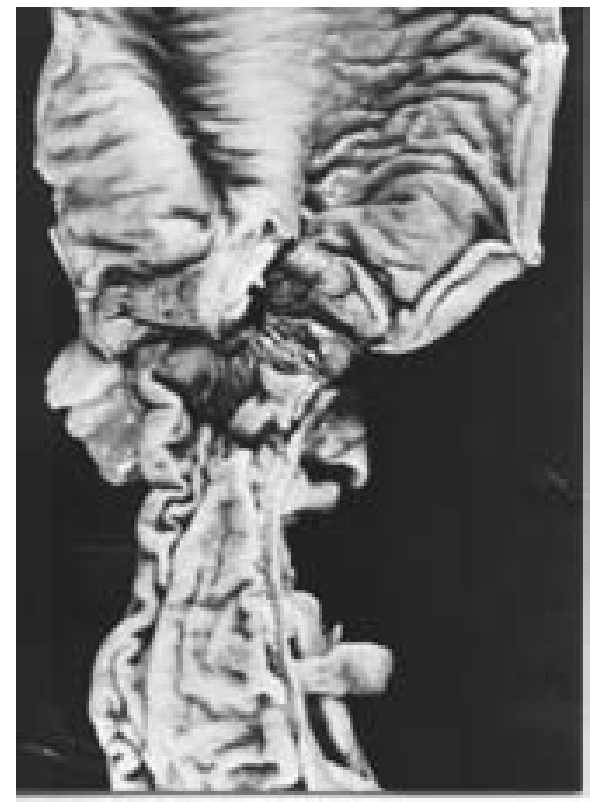

Figure 2 - Surgical specimen showing evidence of annular tumor in the colon, causing stenosis. Observe dilatation and hypertrophy of the wall in the proximal segment, and hypertrophy of the wall in the distal part. 
chronic ganglionitis, denervation with hypertrophy of the residual neurons in the myenteric plexus, chronic myositis and fibrosis (Figure 3 ). Counting of the number of neurons in the myenteric plexus was done in 10 step sections from a ring of tissue cut out from close to the tumor at the descending colon-sigmoid transition, and from another ring distal to the neoplasia at the recto-sigmoid transition, in conformity with a methodology previously utilized in another study by one of the authors ${ }^{3}$. Following this methodology, the perikaryons of 30 neurons of the myenteric plexus were measured in the same regions. The average diameter of the neurons in the descending colonsigmoid transition, in micrometers, were $33.0 \pm 7.9$ and in the recto-sigmoid transition $37.8 \pm 16.9$, demonstrating neuronal hypertrophy (Figure 4). The

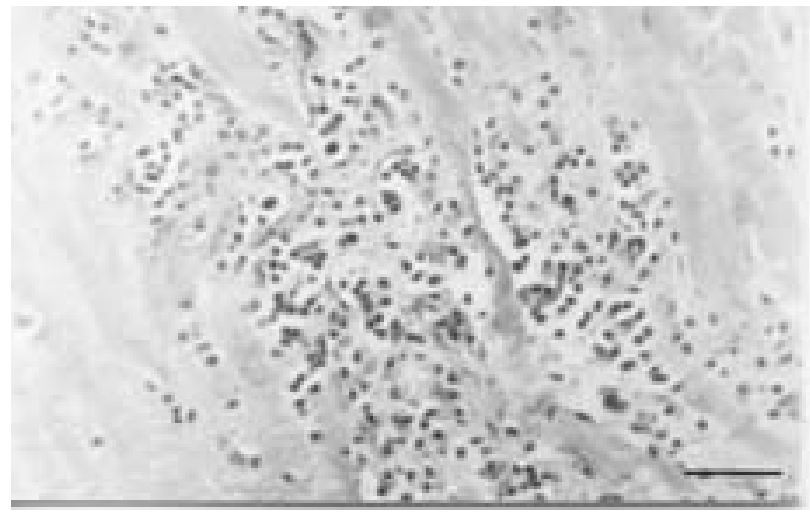

Figure 3 - Histological section through the muscle tunica of the recto-sigmoid transition (distal to the tumor), showing the chronic myositis seen in chagasic megacolon (scale bar $=200 \mu \mathrm{m}$ ). diameter of these cells in non-chagasic cases is on average $19.3 \pm 2.4 \mu \mathrm{m}$ in the middle portion of the sigmoid $^{3}, 18.6 \pm 1.9$ and $17.5 \pm 1.1 \mu \mathrm{m}$ in the descending colon-sigmoid transition and rectosigmoid transition, respectively ${ }^{2}$ (Figure 5). The neuron count in the myenteric plexus of the case reported here, after applying the correction factor due to the hypertrophy ${ }^{2}$, resulted in 2,041 neurons in the descending colon-sigmoid transition and 1,171 in the recto-sigmoid transition. This corrected value for the recto-sigmoid transition provides evidence of a denervation of $53.9 \%$ in comparison with the average value obtained in non-chagasic cases utilizing the same methodology, which was on average $2,538^{2}$.

Atelectasis and pneumonia at the base of the left lung were presented as postoperative complications,

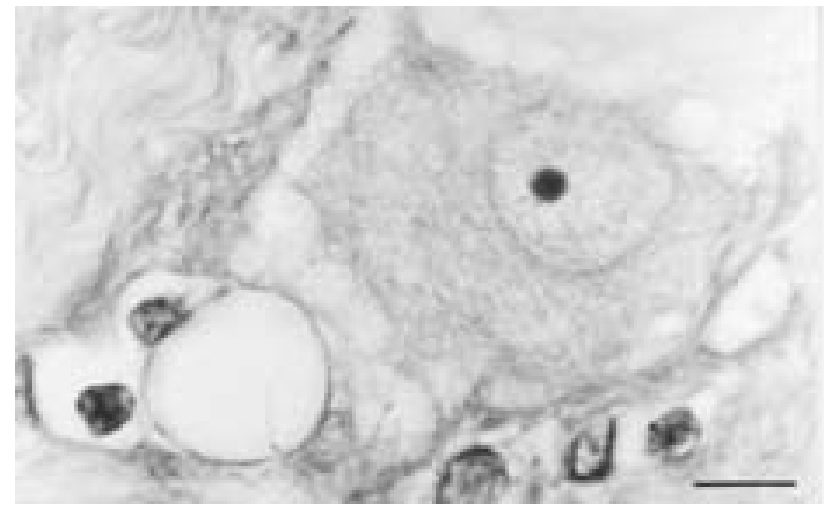

Figure 4 - Neuron from the myenteric plexus of the recto-sigmoid transition (distal to the tumor), presenting hypertrophy (scale bar $=20 \mu \mathrm{m}$ )

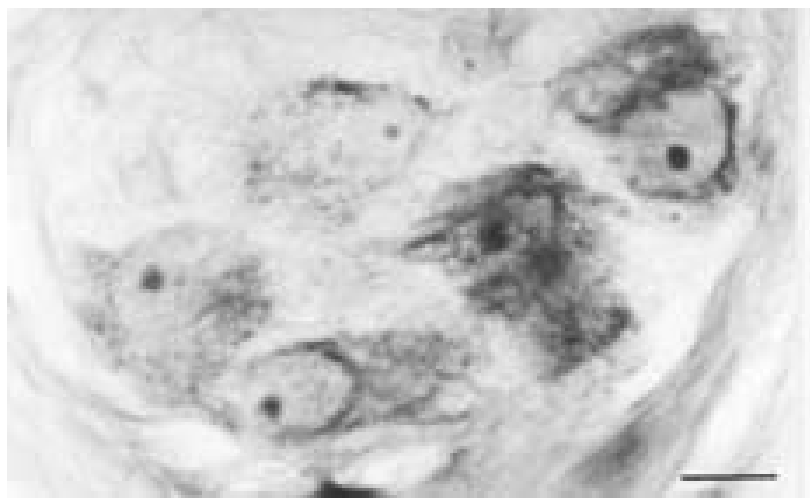

Figure 5 - Normal-sized neuron from the myenteric plexus of the colon of a non-chagasic individual, without intestinal pathology, for comparison with Figure 4 (scale bar $=20 \mu \mathrm{m}$ ).

with satisfactory evolution after clinical treatment. Release from hospital was given on the $12^{\text {th }}$ postoperative day. Six months later, the following checkups were performed: radiology (simple radiography of the thorax, ultrasonography and computerized tomography of the abdomen, and barium enema), endoscopy (colonoscopy) and laboratory tests (dosage of carcino-embryonic antigen). These did not show evidence of metastases. He underwent reconstruction of the intestinal transit, with colorectal anastomosis via mechanical suture, with good evolution up to the present time (20 months). 


\section{DISCUSSION}

The diagnosis of megacolon in this case merits some comments. As this concerned a tumor causing stenosis in the sigmoid, it could at first have been thought that the hypertrophy and dilatation proximal to the neoplasia would just be the result of a mechanical effect. However, the hypertrophy seen in this case was much more intense than that usually found in neoplasias causing stenosis. Experimental studies with the inducement of mechanical stenosis are not associated with a reduction in the number of neurons ${ }^{59}$ and, on the contrary, there even exist reports of increases in the number of neurons ${ }^{9}$. In addition to this, there was also neuronal hypertrophy at the rectosigmoid transition, i.e. distal to the tumor, which could not be explained by neoplastic stenosis. Furthermore, the degree of denervation seen in this case was almost $55 \%$, which is in accordance with the data from Köberle ${ }^{16}$, Adad $^{2}$ and Adad et $\mathrm{al}^{3}$ that megacolon becomes installed in chagasic cases with denervation generally greater than $50 \%$ or $55 \%$. The disproportion between the dilatation of the part that is distal to the tumor, in relation to the proximal part, is probably the result of the distal portion becoming dysfunctional due to the chronic obstruction of the colon resulting from the neoplasia. Köberle ${ }^{15}$ has reported that marked regression may occur in a megacolon in the section of the intestine which has been excluded for a few weeks before operation by a colostomy in transverse colon. The contrast between the radiograph made before colostomy and the specimen obtained on resection a few weeks later is striking.

In the medical literature we found reference to an association between colorectal cancer and chagasic megacolon in 8 patients, although only 3 cases were described with clinical and/or anatomicopathological details ${ }^{21} 23$. Three cases were indicated as personal communications by Lopes ${ }^{18}$ and Meneses et al ${ }^{20}$ In these three cases there was an association with intestinal polyps, and the carcinomas were localized in the right colon, recto-sigmoid and rectum. Meneses et $\mathrm{al}^{20}$ in a series of 198 cases of necropsies performed on chagasic megacolon, found a single case of colorectal cancer localized in the rectum, and no case of neoplasia was identified from 129 surgical specimens of chagasic megacolon. Garcia ${ }^{10}$ reported that from 802 surgical resections due to megacolon, there was a single case of cancer, localized in the rectum, which was not taken into consideration because the neoplasia was not situated in the dilated intestinal segment. In the last three cases described ${ }^{21} 23$ the adenocarcinoma was localized in the transverse colon and none of them was associated with polyposis. In one case there was dolichomegasigmoid and diverticular disease ${ }^{21}$, in another only dolicho-megasigmoid, and megarectum and megasigmoid in the latter ${ }^{23}$.

Putting together all the findings of megacolon made in regions where Chagas' disease is endemic, there have only been $2(0.1 \%)$ cases of colon cancer from 1,449 surgical specimens and/or necropsies researched ${ }^{10132030}$ (Table 1). On the contrary, an increased frequency of cancer in megaesophagus is noted: out of 1,265 cases of megaesophagus ${ }^{1678262729}$ there were 61 (4.8\%) cases of cancer (Tabela 2).

Experimental cases confirm the data observed in human Chagas' disease, in which megacolon appears to be associated with a lower frequency of colorectal cancer. Oliveira ${ }^{23}$ and Oliveira et $\mathrm{al}^{24}$ compared the frequency of benign and malignant colonic tumors chemically induced in Wistar rats, with and without chronic infection by $T$. cruzi, and verified a lower

Table 1 - Sampled works on megacolon.

\begin{tabular}{lccc}
\hline & & \multicolumn{2}{c}{ Cases of colorectal cancer } \\
\cline { 3 - 4 } Authors & Cases of megacolon & $\mathrm{nr}$ & $\%$ \\
\hline Rocha et al & & & \\
& 120 & 0 & 0.0 \\
Meneses et al $^{20}$ & 327 & 1 & 0.3 \\
Henry et al $^{13}$ & 200 & 0 & 0.3 \\
Garcia $^{10}$ & 802 & 1 & 0.1 \\
\hline Total & 1,449 & 2 & 0.1 \\
\hline
\end{tabular}

Table 2 - Sampled works on megaesophagus.

\begin{tabular}{lcrc}
\hline & & \multicolumn{2}{c}{ Cases of colorectal cancer } \\
\cline { 3 - 4 } Authors & Cases of megacolon & $\mathrm{nr}$ & $\%$ \\
\hline Câmara Lopes $^{7}$ & 90 & 7 & 7.7 \\
Ferreira-Santos $^{8}$ & 155 & 8 & 5.2 \\
Pinotti et al $^{27}$ & 308 & 12 & 3.9 \\
Rocha et al $^{29}$ & 107 & 5 & 4.6 \\
Brandalise et al $^{6}$ & 140 & 13 & 9.2 \\
Abreu et al $^{1}$ & 142 & 5 & 3.5 \\
Paiva et al & & &
\end{tabular}

frequency in the chagasic group, even without developing megacolon. Garcia ${ }^{10}$ and Garcia et al $^{11}$ induced megacolon chemically, applying benzalkonium chloride to the serosa of the colon in Wistar rats, and afterwards administrating dimethyl-hydrazine, which induces carcinogenesis of the colon. A significant decrease in the number of animals with tumors in the distal colon was verified in the group with megacolon. Hypotheses were raised to explain these apparently paradoxical results, both in humans and in the experimental studies, in which the megacolon appeared to be associated with lower frequency of colorectal cancer, despite the long time with obstipation with consequent prolonged fecal stases that could predispose to carcinogenesis. Reference was made to the fact that intraluminal factors such as bacterial flora and $\mathrm{pH}$ could be altered in megacolon, just like parietal factors because 
of modifications to the components of the intestinal wall as a consequence of visceromegaly, which could result in alterations in the levels of neurotransmitters, neuropeptides or other factors still to be studied ${ }^{1011}$. Alterations in activities of nitric oxide synthase was demonstrated in the gut of $T$. cruzi- infected mice ${ }^{22}$.

The proven association between neoplasia of the esophagus and idiopathic achalasia or chagasic megaesophagus is probably a consequence of the chronic esophagitis caused by alimentary stasis and of prolonged contact by the mucosa with carcinogens in the diet. Nevertheless, the rare occurrence of cancer in chagasic megacolon, despite the presence of fecal stasis, chronic irritation and exposure to carcinogenic factors, appears to contradict the traditional concepts in carcinogenesis of the colon. The association between chagasic megacolon and neoplasia merits further clinical observations and experimental trials, to permit better understanding.

\section{REFERENCES}

1. Abreu RB, Quaglieri P, Ribeiro MF, Corsi PR, Castro LT, Gagliardi D, Viana AT, Fava J. Megaesôfago: doença precursora do câncer de esôfago. Revista Brasileira de Cirurgia 80:91-94, 1990.

2. Adad SJ. Contribuição ao estudo da anatomia patológica e patogênese do megacólon chagásico. Tese de Doutorado, Faculdade de Medicina do Triângulo Mineiro, Uberaba, MG, 1996.

3. Adad SJ, Cançado CG, Etchebehere RM, Teixeira VPA, Gomes VA, Lopes ER, Chapadeiro E. Neuron count reevaluation in the myenteric plexus of chagasic megacolon after morphometric neuron analysis. Virchows Archives 438:254-258, 2001.

4. Adad SJ, Etchebehere RM, Hayashi EM, Asai RK, Fernandes PS, Macedo CFC, Crema E. Leiomyosarcoma of the esophagus in a patient with chagasic megaesophagus: case report and literature review. The American Journal of Tropical Medicine and Hygiene 60:879-881, 1999.

5. Barbosa AJA, Tafuri WL. Ganglion cell number in hypertrophic colon above experimental stenosis. Brazilian Journal of Medicine and Biological Research 16:165-169, 1983.

6. Brandalise NA, Andreollo NA, Leonardi LS, Callejas Neto F. Carcinoma associado a megaesôfago chagásico. Revista do Colégio Brasileiro de Cirurgiões 12:196-199, 1985.

7. Câmara-Lopes LH. Carcinoma of the esophagus as a complication of megaesophagus. American Journal of Digestive Disease 6:742-756, 1961.

8. Ferreira-Santos R. Tratamento cirúrgico da aperistalse esofágica (megaesôfago): análise crítica da experiência do Departamento de Cirurgia da Faculdade de Medicina de Ribeirão Preto. Tese de Doutorado, Universidade de São Paulo, Ribeirão Preto, SP, 1963.

9. Gabella G. Size of neurons and glial cells in the intramural ganglia of the hypertrophic intestine of the guinea-pig. Journal of Neurocytology 13:73-84, 1984.

10. Garcia SB. O câncer no megacólon: estudos da incidência no homem e experimental em ratos. Tese de Doutorado. Faculdade de Medicina de Ribeirão Preto da Universidade de São Paulo, Ribeirão Preto, SP, 1995.

11. Garcia SB, Oliveira JSM, Pinto LZ, Muccillo G, Zucoloto S. The relationship between megacolon and carcinoma of the colon: an experimental approach. Carcinogenesis 17: 1777-1796, 1996.

12. Goldblum JR, White RI, Orringer MB, Appelman HD. Achalasia: a morphologic study of 42 resected specimens. American Journal of Surgical Pathology 18:327-337, 1994.

13. Henry MACA, Mendes EF, Prado RG, Saad LHC, GonçalvesJúnior I, Macedo AR. Megacólon: análise de 200 pacientes submetidos a tratamento cirúrgico. Revista Goiana de Medicina 35:25-33, 1989.
14. Huggins D. Carcinoma do esôfago associado ao megaesôfago chagásico (relato de um caso). Anais do Instituto de Higiene e Medicina Tropical 4:57-62, 1976.

15. Köberle F. Enteromegaly and cardiomegaly in Chagas' disease. Gut 4: 399-405, 1963.

16. Köberle F. Chagas' disease and Chagas' syndromes: the pathology of American trypanosomiasis. Advances in Parasitology 6:63-116, 1968.

17. Livstone EM, Skinner DB. Tumors of the esophagus. In: Berr JE (ed). Bockus Gastroenterology, $4^{a}$ edição, WB Saunders Co, Philadelphia, p.814-840, 1985.

18. Lopes ER. Megaesôfago, megacólon e câncer. Revista da Sociedade Brasileira de Medicina Tropical 21: 91-94, 1988.

19. Lustig ES, Puricelli L, Lansetti JC. Association of Chagas' disease and cancer. Medicina 40:43-46, 1980.

20. Meneses ACO, Lopes MAB, Rocha A, Fatureto MC, Lopes GP, Lopes ER, Chapadeiro E. Megas e câncer. Câncer de intestino grosso em chagásicos com megacólon. Arquivos de Gastroenterologia 26:13-16, 1989.

21. Miranda JAR, Oliveira EC, Moreira JPT, Luquetti AO, Moreira H. Megacólon chagásico e câncer de cólon: relato de caso. Revista da Sociedade Brasileira de Medicina Tropical 29 (supl):126, 1996.

22. Ny L, Persson K, Larsson B, Chan J, Weiss LM, Wittner M, Huang $\mathrm{H}$, Tano HB. Localization and activity of nitric oxide synthesis in the gastrointestinal tract of Trypanosoma cruzi-infected mice. Journal of Neuroimmunology, 99:27-35, 1999.

23. Oliveira EC. Associação entre infecção crônica pelo Trypanosoma cruzi e câncer de cólon. Estudo experimental em ratos. Tese de Mestrado, Universidade Federal de Goiás, Goiânia, GO, 1998.

24. Oliveira EC, Leite MSB, Miranda JA, Andrade AL, Garcia SB, Luquetti AO, Moreira H. Chronic Trypanosoma cruzi infection associated with low incidence of 1,2-dimethylhydrazine-induced colon cancer in rats. Carcinogenesis 22:737-740, 2001.

25. Oliveira EC, Leite MSB, Ostermayer AL, Almeida AC, Moreira H. Chagasic megacolon associated with colon cancer. American Journal of Tropical Medicine and Hygiene 56:596-598, 1997.

26. Paiva ALC, Garcia-Rodrigues AC, Aranha Al, Britto-Garcia S, Iglesias AC, Zucoloto $S$. Correlação entre a incidência de câncer de esôfago e o megaesôfago chagásico. Estudo retrospectivo de 323 casos operados no HC-FMRP/USP. In: Resumos do III Fórum de Iniciação Científica em Clínica Cirúrgica e Cirurgia Experimental da FMRP/USP, Ribeirão Preto, 1995.

27. Pinotti HW, Pollara WM, Gemperi R, Raia AA. O problema do câncer no megaesôfago. Revista da Associação Médica Brasileira 26:379-381, 1980 
28. Rezende JM, Rosa H, Vaz MGM, Andrade-Sá N, Porto JD, Neves Neto J, Ximenes JA. Endoscopia no megaesôfago. Estudo prospectivo de 600 casos. Arquivos de gastroenterologia 22:53-62, 1985.

29. Rocha A, Almeida HO, Esper FE, Moraes DM, Santos EP, Teixeira VPA. Associação entre megaesôfago e carcinoma de esôfago. Revista da Sociedade Brasileira de Medicina Tropical 16:94-97, 1983.

30. Rocha A, Henrique D, Borges EG, Oliveira VL, Soares VMG, Moraes AT, Teixeira VP, Almeida HO. Complicações do megacólon e megaesôfago chagásicos observadas em necrópsia. Revista Goiana de Medicina 27:53-62, 1981.

31. Sandler RS, Nyrén O, Ekbom A, Eisen GM, Yuen J, Josefson S. The risk of esophageal cancer in patients with achalasia. A population-based study. Journal of the American Medical Association 274:1359-1362, 1995. 